\title{
THE ACCUSATION OF COMMUNISM AS SLANDER PER SE
}

IT IS GENERALLY held that an accusation of Communism in reriting is libellous and actionable per se. ${ }^{1}$ Any doubt as to the defamatory character of such an accusation may well be settled by a glance at Joint Anti-Fascist Committee v. McGrath, ${ }^{2}$ where it was held to constitute the gravamen of a good cause of action. There is some question, however, as to whether an oral accusation of Communism is likewise actionable per $s e .^{3}$

The law of slander almost universally distinguishes between types of defamation-some being held actionable only upon proof of special damages, and others being held actionable per se, damages being conclusively presumed. ${ }^{4}$ The pressures which forced this branch of the law, in its budding years, into this rather arbitrary and much criticized pattern are not germane to this discussion. It suffices merely to note that this long-standing distinction seems to have had its genesis in the common law courts' choice of a form of action for this class of wrongsnamely, an action on the case-when jurisdiction was first assumed over them. From this, it inevitably followed that temporal damage rather than impairment of the intangible interest of reputation was to be the gist of the cause of action. ${ }^{5}$

As a result, unless allegedly defamatory words are of a sort which automatically causes the presumption of damages to attach, the plaintiff must prove some specific pecuniary loss directly attributable to their utterance as an essential element of his cause of action. ${ }^{6}$ Only after such damages are proven may general damages be recovered for the injury theoretically underlying the cause of action-impairment of the plaintiff's reputation. ${ }^{7}$ Since, however, there seems to be no logical reason to suppose that an injury to reputation will necessarily be accom-

${ }^{1}$ See, e.g., Notes, x7x A.L.R. 709 (1947); 5x A.L.R. xo7x (1927).

2341 U.S. I23, 139 (195 I).

${ }^{3}$ Compare Pecyk v. Semoncheck, I05 N.E.2d 6I (Ohio 1952), with Lightfoot v. Jennings, 254 S.W.2d 596 (Mo. r953).

- It would probably be clearer to say that in the case of slander per se special pecuniary damages are not an essential element of the cause of action, but the terminology is traditional. See Odgers, Libel AND SLANDER 2 (6th ed. ig29).

${ }^{\circ}$ Holdsworth, Defamation in the Sixteenth and Seventeenth Centuries, 40 L.Q. Rev. 302, 304 (1924); Restatement, ToRTs $§ 568$, comment 6 (1938).

${ }^{\circ}$ MCCoRMick, Damages $\S$ II 5 (ist ed. 1935).

${ }^{7}$ I Street, Foundations of Legal Liability 274 (ist ed. x906). 
panied by provable money damages, ${ }^{8}$ the law, by conditioning a remedy in some cases on such proof, only partially shields the interest it purports to protect. The availability of a remedy for an admittedly defamatory statement may thus depend on nothing more significant than, for example, whether the plaintiff's friends, who will no longer receive him, formerly served him food during his calls. ${ }^{9}$

Where, on the other hand, a defamatory utterance is classifiable as slander per se and damages are conclusively presumed, the defamer is put upon proof of the truth of his accusation, his privilege, or some other defense if he is to escape liability. ${ }^{10}$ Of the several catagories of defamation traditionally considered slanderous per se, only two are relevant to the present problem: those imputing unfitness in respect of one's office, profession, or business; ${ }^{11}$ and those imputing criminality. ${ }^{12}$

\section{The Accusation of Communism as an Imputation of Professional Unfitness}

For a statement which imputes unfitness in respect of one's office, profession, or business to be slanderous per se, it is necessary that at least a substantial part of the general public would believe that, if the accusation were true, the plaintiff would lack the qualities they expect from one of his calling. ${ }^{13}$ Although some courts have required that the allegedly defamatory words be spoken of the plaintiff with specific reference to his office, profession, or business, the position of the majority is:

It is not necessary that the defamer refer to the other as engaged in the particular profession or calling in question. It is enough if the statement is of a character to be particularly disparaging of one engaged in such an occupation. ${ }^{14}$

The inclusion within this category of accusations that government officials are affiliated with groups believed by a substantial segment of the public to be disloyal and subversive is not novel. In 1590, an accusation that a government official was not a "true subject" was held to be actionable per $s e,{ }^{15}$ as were charges that government officials were

${ }^{8}$ Prosser, ToRts $\$ 92$ at pp. 805-806 (1st ed. 1941).

${ }^{\circ}$ Moore v. Meagher, I Taunt. 39, 127 Eng. Rep. 745 (1807).

${ }^{10}$ See generally Chapter 25, RESTATEMENT, ToRTs (1938).

${ }^{11}$ I Street, Foundations of Legal Liability 277 (ist ed. 1906); Prosser, TORTS $\S 92$ at p. 802 (ist ed. I941); REsTatement, ToRTS $\$ 573$ (1938).

${ }^{12}$ Odgers, Libel and SLANDER 35 (6th ed. 1929); Restatement, Torts $\$ 571$ $(1938)$.

${ }_{13}$ Prosser, Torts $\S 92$ at pp. 802-804 (1st ed. 1941); Restatement, Torts $\S 573$, comment $d(1938)$.

${ }^{14}$ RestATEMENT, TORTS $\S 573$, comment $e$ (1938). The question is ordinarily one for the jury. Restatement, ToRTs $\S 615$ (2), comment $b$ (1938).

${ }^{15}$ Waldegraves v. Agas, Cro. Eliz. 191, $7^{8}$ Eng. Rep. 447 (1590). 
"papists" in $168 \mathrm{I}-\mathrm{I} 682,{ }^{16}$ or that one was a "Jacobite" and supporter of the Pretender in $1702 .{ }^{17}$ That the characterization of these utterances as slanderous per se was based on the plaintiffs' holding public office clearly appears from the rejection of identical contemporary actions brought by private persons. ${ }^{18}$

Adapting this theory to modern times, it was recently held in Remington v. Bentley ${ }^{19}$ that an accusation that a government economist was a member of the Communist Party was slanderous per se. Supporting this conclusion, the court noted that a Communist in our society is widely considered to be both unfitted for government employment and unsound as an economist. ${ }^{20}$ This thesis is further reinforced by recent legislation designed to oust from government employment subversives generally and Communists particularly. The Internal Security Act of $1950^{21}$ makes it unlawful for any member of a Communist organization to hold non-elective office or employment in the federal government. The Hatch $\mathrm{Act}^{22}$ requires the discharge from federal employment of a member of any political party or organization which advocates the overthrow of our constitutional form of government. Among the several analogous state enactments are statutes in five jurisdictions specifically excluding from "state employment" persons directly or indirectly affiliated with the Communist Party; ${ }^{23}$ statutes in three jurisdictions excluding such persons from "public office"; ${ }^{24}$ and statutes in five jurisdictions barring them from "elective office."25 Of course, there is considerable overlapping, and similar statutes in several other jurisdictions, although not expressly mention-

${ }^{10}$ Clarges v. Rowe, 3 Lev. 30, 83 Eng. Rep. 56I (168I); Stawel v. Caune, 3 Lev. 50, 83 Eng. Rep. 571 (I68I); Knightly v. Marrow, 3 Lev. 68, 83 Eng. Rep. $581 \quad(1682)$.

${ }^{17}$ How v. Prin, 7 Mod. 107, 87 Eng. Rep. I128 (1702).

${ }^{18}$ Compare Fowler v. Aston, Cro. Eliz. 268, 78 Eng. Rep. 523 (1592), and Smith v. Turner, Yel. 104, 80 Eng. Rep. 70 ( 1608 ), with cases cited note 16 supra.

${ }^{10} 88$ F. Supp. 166 (S.D.N.Y. 1949).

20 Id. at $17 \mathrm{I}$.

${ }^{21} 64$ STAT. 987,992 (I950), 50 U.S.C.A. $\$ 784$ (I951).

2253 STAT. I 48 (1939), 5 U.S.C.A. \$ I 8 j (1949).

23 Alaska Laws, 1949, c. 113, p. 290; ARK. STAT. ANN. $4_{41-4113}$ (c) (1947); Fla. Stat. Ainn. $\$ \$ 876.05-876.10$ (Supp. I952); GA. CoDE ANN. \$\$ 89-311-89-3 I6 (Supp. 1949), as amended by Ga. Laws I950, Vol. I, p. 282 ; ILl. REV. STAT. c. $241 / 2$ \& 8 (1949).

24 Alaska statute supra note 23 ; Florida statute supra note 23 ; OKLA. STAr. tit. 5 I, $\$ \$ 31-35$ (1950).

${ }_{20}$ Alaska statute supra note 23; Florida statute supra note 23; Oklahoma statute supra note 24; Arizona Laws I949, H.R. 4, p. 570; GA. CODE ANN. \$ 89-315 (Supp. 1949). 
ing Communists, would also clearly seem to bar them from similar positions. ${ }^{26}$

Of course, in order to make out a case of slander per se under this rubric, it is not at all necessary that the accusation, if true, statutorily bar one from his calling. ${ }^{27}$ Nevertheless, where they exist, these statutes would seem to afford a clear index of prevalent popular opinion as to the fitness-or unfitness, if you will-of Communists for public service, thus more readily conducing the conclusion that an accusation of Communism directed against a public servant is slanderous per se.

The characterization of accusations that teachers are Communists as slanderous per se seems equally compelling. The Association of American Universities has recently stated its position to be that espousal of Communism is, inter alia, an espousal of world revolution entailing a surrender of intellectual integrity, and that "no person who accepts such principles has any place in a University."28 Furthermore, teachers who are Communists are specifically excluded from state employment by statute in Alaska, ${ }^{20}$ Georgia, ${ }^{30}$ New Hampshire, ${ }^{31}$ and Texas, ${ }^{32}$ and by requirements set by administrative bodies pursuant to statute in New York, ${ }^{33}$ Rhode Island, ${ }^{34}$ and Virginia. ${ }^{35}$

${ }^{26}$ In six jurisdictions, statutes exclude persons from elective office who are members of organizations which advocate forcible or unlawful overthrow of the government or programs of force, violence, treason, and sedition. Alaska and Florida statutes, supra note 23; Oklahoma law, supra note 24; Kansas Laws, 1949, c. $246 \$ 1$ 1, p. 407;

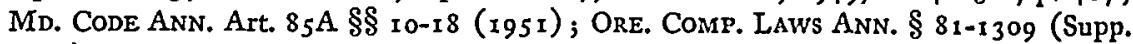
I943). Eight jurisdictions bar such persons from "public office." Alaska and Florida statutes, supra note 23; Oklahoma statute, supra note 24; Maryland statute, supra this note; Kansas Laws, supra this note; HawaII REv. LAws $\S \S 600-616$ (1945), as amended by Hawaii Laws 1945, Art. 131, p. 22, as amended by Hawaii Laws I947, Art. II7, P. 26; ILl. REv. STAT., c. 127 166a (1949); N.Y. PUb. OFF. LAW $\S 35 \mathrm{a}$ (1952). Thirteen bar them from "state empoyment." Alaska and Florida statutes, supra note 23; Kansas, Hawaii, Illinois, and Maryland statutes, supra this note; MAss. ANN. LAws, c. 264 $\$ \S 14$, I5, 20 (Supp. 1952); N.Y. Civil Ser. LAW $\$ \S$ 12a, $23 a$ (1946); N.C. GeN. Stat. § 14-12.I (Supp. 1951); PA. ANN. tit. 53, $\$ 35$ I.13 (Supp. 1952); Oregon Laws 1949, c. 311 ; WASH. REv. CODE, c. 9.8r.040-9.18.060 (I95I). The statutes relating to state cmployment would seem in most instances broad enough to cover public teachers.

${ }^{27}$ Authorities cited supra note $13 . \quad{ }^{28}$ Time, April 6, 1953, p. 53.

${ }^{20}$ Alaska statute, supra note 23 .

${ }^{30}$ GA. CODE ANN. \$§ 89-31I, 314, 316 (Supp. 1949).

${ }^{31}$ N.H. Laws 1949, c. 312, p. 414.

${ }^{32}$ Tex. Rev. Civil Stat. Art. 2908a (195I).

${ }^{33}$ N.Y. Education Laws $\S \S 302 \mathrm{I}-3022$ (1953). This is the controversial Feinberg law.

${ }^{34}$ See Rules and Regulations adopted January $1,193^{8}$, by the Rhode Island State Board of Education governing issuance of teachers' certificates under R.I. Gen. Laws, c. ${ }_{176}, \S \S_{1-2}\left(193^{8}\right)$.

${ }^{36}$ VA. CODE $\oint_{22-207}(1950)$. The teacher's oath is embraced in the employment contract. 
Accusations of Communism directed against clergymen would also seem to fall within this category because of the strong overtones of atheism which such an accusation imports.

Although, as a practical matter, an accusation of Communism probably jeopardizes the economic as well as social status of other classes of persons, ${ }^{30}$ the law takes no cognizance of this fact in the absence of provable proximate pecuniary damages. Accordingly, only if the accusation of Communism is held to impute criminality can the average individual avoid the onus of proving special damages as an essential element of his cause of action for slander.

\section{The Accusation of Communism as an Imputation of Crime}

Whether or not an accusation of Communism imputes a criminal offense necessarily involves some inquiry into the existence and incidence of sanctions imposed for affliation with subversive groups or organizations. The legislation pertinent to such an inquiry is contained in three federal statutes: (I) the Seditious Conspiracy Act ${ }^{37}$ (2) the Smith Act, ${ }^{38}$ and (3) certain portions of the Internal Security (McCarran) Act of $1950 ;^{39}$ and several state statutes.

The Seditious Conspiracy Act reads in part:

If two or more persons ... conspire to overthrow, put down, or to destroy by force the government of the United States . . . they shall each be fined not more than $\$ 5,000$ or imprisoned not more than six years, or both. ${ }^{40}$

The Smith Act provides, inter alia:

Whoever organizes or helps or attempts to organize any society, group, or assembly of persons who teach, advocate, or encourage the overthrow or destruction of any such government by force or violence, or becomes or is a member of, or affiliates with, any such society, group, or assembly of persons, knowing the purposes thereof-

Shall be fined not more than $\$ 10,000$ or imprisoned not more than Io years, or both. ... ${ }^{41}$

There is some question as to the effect of the Internal Security Act of 1950 on the existing criminal law relating to subversive activities, springing primarily from $\S 4(f)$ which reads in part:

${ }^{30}$ The public attitude seems fairly well expressed by a novel Montana Statute. Mont. Rev. Code $\$ 77-606$ (I947).

${ }^{37} 62$ STAT. 808 (1948), 18 U.S.C.A. $\$ 2384$ (I95I).

${ }^{38} 62$ STAT. 808 (1948), 18 U.S.C.A. $\$ 2385$ (195I).

${ }^{30} 64$ STAT. 987-1019 (1950), 50 U.S.C.A. $\$ \$ 78 I-826$ (1951).

- Supra note 37. Held applicable to Communist organization in civil litigation in Burke v. American Legion of Ohio, 14 Ohio. App 243 (I921).

${ }^{11}$ Supra note 38 . 
Neither the holding of office nor membership in any Communist organization by any person shall constitute per se a violation of subsection (a) or subsection (c) of this section or of any other criminal statute. ${ }^{42}$ (Italics supplied.)

$\S$ I7 of the same Act provides:

Existing criminal statutes. The foregoing provisions of this Title (Title I, including section 4 (f)) shall be construed as being in addition to and not in modification of existing criminal statutes. ${ }^{43}$

Since other sections of the Internal Security Act make registration mandatory for officers and members of Communist organizations, ${ }^{44}$ $\S 4(f)$ would appear to have been designed to forestall claims that compliance therewith would be self-incriminating. The words "or of any other criminal statute" would thus appear to be solely intended to perfect the registrant's shield against self-incrimination in this connection ${ }^{45}$ - a conclusion fortified by adversion to the words "per se" and to $\S I 7$ with its express disclaimer of any intention to modify the existing criminal law.

To construe $\S 4(f)$ more broadly-as eradicating every taint of criminality attaching to membership in a Communist organization with knowledge of its forbidden purposes-would present serious difficulties. First, such construction would ignore the words "per se." Second, it would create an internal conflict within the Act between $\S \S 4(f)$ and I7. And, third, it would prefer Communists over other subversivesa result seemingly directly antithetical to the underlying legislative intent to provide further safeguards against the menace of Communism, rather than relax the existing ones. ${ }^{46}$ Therefore, it would clearly appear that $\S 4(f)$ was not intended to and does not, in fact, alter the older Smith Act.

It seems indeed doubtful that legislation designed to impede Communist activity could constitutionally be more direct and severe than the existing federal statutes, ${ }^{47}$ and most states which have enacted similar legislation have not attempted to go farther. Even the Florida statute, cast specifically in terms of "Criminal Communism," apparently

1264 STAT. 992 (1950), 50 U.S.C.A. $\$ 783$ (f) (1951).

1364 STAT. 1003 (I950), 50 U.S.C.A. \& 796 (195I).

${ }^{14} 64$ STAT. 995 (1950), 50 U.S.C.A. $\$ 787$ (1951).

15 Legis., 5 I Col. L. REv. 619 (195I).

${ }^{46} 64$ STAT. $987-989$ (1950), 50 U.S.C.A. § 781 (1951), U.S. CODE CONG. SERv., 1950, Vol. 2, pp. 3886-3892, H.R. REP. 2980; 96 Cong. Rec., pp. 14167-15770 (1950).

${ }^{17}$ Herndon v. Lowery, 301 U.S. 242 (1937). 
requires proof of the same facts for conviction as does the Smith Act. ${ }^{48}$ Only in Massachusetts is legislation dealing with Communist activity more stringent. There the Communist Party is declared by statute to be a subversive organization, and membership therein with knowledge of its declared subversive character is punishable by fine and/or imprisonment. $^{40}$

A violation of the Seditious Conspiracy Act involves the familiarly intricate common law conspiracy with its congeries of technical and complex factual elements. ${ }^{50}$ Accordingly, to impute violation of this legislation, an accusation would seemingly have to be couched in rather specific and technical terms. While such statements are possible, they will probably be quite rare.

As a practical matter, then, the only statutes whose violations may ordinarily be imputed from an accusation of Communism are the Smith Act, those state statutes cut to the same pattern, and the Massachusetts legislation discussed above. Since, as a general rule, a statement imputing a violation of the state statutes following the Smith Act pattern would, in all probability, impute a violation of the Smith Act itself, attention here will be focused on this latter legislation. The Massachusetts legislation, too, being sui generis, will be noted specifically, albeit in a limited manner commensurate with its limited territorial effect.

The practical effect of this legislation is that everywhere within the United States today it is a felony to be a member of, or affiliate with, any group or organization which teaches, advocates, or encourages the violent overthrow of our government, knowing the character of that group. Whether or not membership in the Communist Party and its so-called "front organizations," outside of Massachusetts, falls under the ban of this legislation is problematical. This problem, however, is entirely separate from the question of whether or not a statement that one is a Communist can reasonably bear the meaning that one has violated this legislation-and it is to the latter problem, not the former, that attention is here directed.

The question arises as to the respective functions of court and jury in determining whether a statement is slanderous per se as imputing a crime. $\S 6 \pi 5(\mathrm{I})$ of the Restatement of Torts makes it clear that the court is to decide whether the crime imputed is of sufficient gravity to render the statement actionable per se. However, that section is silent as regards the role of court and jury in determining a preliminary question when the statement is ambiguous, i.e., what crime, if any, has been

${ }^{68}$ State ex rel. Benemovsky v. Sullivan, 37 So.2d 907 (Fla. 1948).

${ }^{\circ 0}$ Mass. ANN. Laws, c. 264, $\$ \$$ 16-16a (Supp. 1949).

${ }^{50}$ Instructions to Grand Jury, 30 Fed. Cas. 1036, No. 18,272 (D.C. 1861 ). 
imputed. The comments to $\S 6 \mathrm{I} 4$ indicate that the jury plays an important part in such cases. Perhaps a clearer statement of the rule, although in complete harmony with these comments, is to be found in Mr. Blake Odger's work:

So too, in cases of slander, the Judge usually decides whether the words are, or are not, actionable per se.... If the defendant's words cannot reasonably bear the meaning ascribed to them by the innuendo, and the Judge is clearly of opinion that the words without that meaning are not actionable, he will stop the case. So, too, if the words even with the alleged meaning are not actionable (though pleaders seldom err on that side). But in all other cases, where there is any doubt as to the true construction of the words, the Judge leaves the question to the Jury. ${ }^{51}$

The court, then, must first determine whether or not the utterance will "reasonably bear" the meaning that the plaintiff has violated the law. In the instant context, the problem, therefore, is whether or not an accusation of Communism will "reasonably bear" the meaning that one has violated the Smith Act or the Massachusetts legislation noted.

A violation of the Smith Act embraces at least three elements: (I) membership or affliation with (2) an organization or group teaching, advocating, or encouraging the overthrow of the government by force and violence (3) with knowledge of this forbidden purpose. In determining whether a bare accusation of Communism can "reasonably bear" the meaning, in the sense of factual content, that these prerequisites have been met, the words must be given the meaning "ordinarily attached thereto by persons familiar with the language used.":52

Taking the elements of the crime in the order of their difficulty, it would seem accurate to say that the Communist movement in the United States is popularly thought to be dedicated to the overthrow of the existing form of government by force and violence. Among the reasons expressly adduced for the enactment of the Internal Security Act of I950 was the conviction that the Communist movement is part of a vast interlocking conspiracy seeking the illegal seizure of the reigns of government. $^{53}$ Implicit recognition of the validity of this belief is reflected in various state "anti-subversive" statutes-most graphically illustrated by those of Massachusetts. ${ }^{54}$ Various legislative committees

"1 Odgers, Libel and Slander 94-95 (6th ed. 1929). See also Prosser, Torts 789 (Ist ed. 194I).

${ }^{52}$ Restatement, Torts $\S 563$, comment $c$ (1938); Odgers, op. cit. silpra note 51, p. 93 ; Seelman, Libel and Slander 639-640 (2d ed. 194 $\mathrm{x}$ ).

${ }^{53}$ Supra note 46.

Supra note 49. 
have reached and published the same conclusion, ${ }^{55}$ and the Subversive Activities Control Board has rendered decisions which it would be difficult to sustain on another basis. ${ }^{56}$ A witness may properly refuse to answer questions relating to his affiliation with the Party on grounds that his answers may tend to incriminate him. ${ }^{57}$ And, while courts have refused to take judicial notice that the Communist Party and its affiliated organizations are a conspiracy to overthrow the government by force and violence, ${ }^{58}$ they might judicially notice that this is the prevailing belief at this time. ${ }^{59}$ Accordingly, an accusation of Communism would seem capable of reasonably bearing an imputation of at least this element of the offense.

Membership or affiliation with the group is another element of the crime. Although it is possible, after some reflection, to conjure up an unassociated intellectual who merely believes in Marxist principles, the natural inference flowing from an accusation of Communism would seem to be membership or affliation with the general subversive movement which has made the name familiar. Thus, it would follow that such an accusation could reasonably bear the meaning that one is a member or affliate of an organization proscribed by the Smith Act.

With respect to the remaining element of the offense-awareness of illegal purpose-law unites with logic in permitting the question to go to the jury. As a matter of logic, it would seem that an accusation of Communism can more reasonably bear this meaning than the meaning that one is ignorant of the organization's illegal purposes. Some sort of mental state is essential to the commission of almost any crime and it is generally not required that the pleader aver that the slanderer meant that the accused individual had the requisite mens rea to commit a crime otherwise imputed. ${ }^{60}$ The same rule would seem applicable to the mental element involved in a violation of the Smith Act. In any

zo 1 Things You Should Know About Communism, pp. I3-14, published by House Committee on Un-American Activities, 1949; Preliminary Statement of COMMITTEE ON LAW ENFORCEMENT OF N.Y. LEGISLATURE, 1939, pp. 176-i 79 .

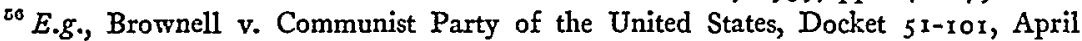
20, 1953, 21 U.S.L. WEEK 2530 (April 28, I953).

${ }^{-7}$ Blau v. U.S., 340 U.S. 159 (1950), rehearing denied, 341 U.S. 912 (1950); Doran v. U.S., 18 I F.2d 489 (9th Cir. I950); Estes v. Potter, 183 F.2d 865 (5th Cir. 1950), cert. denied, 340 U.S. 920 (1950).

${ }^{28}$ Carlson v. Landon, 187 F.2d 991 (gth Cir. 1951), aff'd, 342 U.S. 524 (1952), rehearing denied, 343 U.S. 988 (1952); Stasiukevich v. Nicholls, 168 F.2d 474 (1st Cir. 1948).

${ }^{80}$ Richardson, Evidence $\$ 43$ (5th ed. 1936). In Dennis v. U.S., 183 F.2d 201 ( $2 \mathrm{~d}$ Cir. 1950), Judge Learned Hand noted the prevalence of such opinions regarding Communists, in relation to the problem of securing an impartial jury.

${ }^{\circ 0}$ Keller v. Dean, 57 App. Div. 7, 67 N.Y. Supp. 842 (1900); Miller v. Miller, 8 Johns. 74 (I8II). 
event, an accusation of Communism would seem capable of reasonably bearing the imputation of knowledge of the illicit purposes which the average hearer attributes to Communist organizations.

Thus, it would seem that an accusation of Communism can reasonably bear the meaning, in the sense of factual content, that the accused's conduct has satisfied the elements essential to a violation of the Smith Act, and, a fortiori, the Massachusetts legislation described above.

Accusations of Communism may be protean in form, and understandably may bear other meanings, admittedly defamatory, but not slanderous per se. Defamatory language often presents such ambiguities, for people as a rule do not trouble to consult the applicable legislation in order to slander in the proper statutory language. ${ }^{01}$ Since, then, the only limitations on the manner in which the accusation of Communism can be made are those imposed by the vocabulary, intelligence, and imagination of the defamer, whether or not an imputation of crime is justifiable will depend in each case on the particular words used and the surrounding facts and circumstances. It may, therefore, be illuminating to examine analogous cases in which courts have or have not permitted juries to find imputations of crime.

It has been held in New York that the statement that one is an "Anarchist" may properly be found by the jury to impute a violation of the state criminal anarchy law. ${ }^{02}$ Permitting a jury to find that the word "Blackleg" imputed the statutory offense of dishonesty at cards was affirmed in an early English case by an evenly divided Common Bench. ${ }^{63}$ The epithet "White-Capper" raised similar problems in an Indiana case, but these were left unanswered, the case being decided on other grounds. ${ }^{04}$ The word "Welcher" ${ }^{35}$ has engendered a split of authority, while juries have not been permitted to find that the words "cheat"6 or "swindler" impute criminal offenses.

The crucial question posed by these cases seems to be this: When does a word bear a meaning sufficiently unequivocal to allow a jury to find therein an imputation of a specific criminal offense? None of these cases states any standards for making this determination. Nevertheless, it would seem that the word "Communist" has today acquired a meaning as unequivocally derogatory and criminal in its way as did

${ }^{01}$ SeElman, op. cit. supra note 52 , at 692 .

${ }^{02}$ Von Gerichten v. Seitz, 94 App. Div. ${ }^{130}, 87$ N.Y. Supp. 968 (1904).

${ }^{03}$ Barnett v. Allen, 3 H. \& N. 376, 157 Eng. Rep. 516 (1858).

${ }^{6}$ Divers v. Meredith, 147 Ind. 693, 47 N.E. 143 (1897).

${ }^{65}$ See minor court opinions collected in ODGERs, op. cit. supra, note 51 at pp. 43, 108.

${ }^{66}$ MacIntyre v. Fruchter, 148 N.Y. Supp. 786 (1914); Odgers, Libel AND SLANDER 43 (6th. ed. I929).

${ }^{\circ 7}$ Odgers, op. cit. supra note 66; Perlman v. Golding, L.J. (N.Y. Jan. 10, 1931). 
"Anarchist" and "Blackleg" in their day, thus meeting the unarticulated standards of clarity and universality of meaning adopted in past cases-whatever they may have been. If this conclusion is correct, an accusation of Communism, coupled with an innuendo drawn in terms of the Smith Act, would present a proper case for jury consideration, if the cause of action were otherwise sound.

Assuming that a jury may properly determine whether such an utterance is slanderous per se as an imputation of crime, the Restatement of Torts, $\S 614(2)$, and the comments thereto, indicate that the jury is to be guided by the rule of $\S 563$ :

The meaning of a communication is that which the recipient correctly, or mistakenly but reasonably, understands it was intended to express.

This rule was designed to discover the "meaning" of a defamation only in the sense of its factual content and understandably leaves unanswered the specific question of whether or not an admittedly defamatory utterance imputes a criminal offense. Thus, even after the permissible factual content is determined, a further inquiry into the legal significance of the facts so communicated is essential. To this end, possibly four questions must be answered. First, must the hearer have grasped the factual content of the statement? Second, must he have realized that the statement imputed criminality? Third, is an understanding that general criminality has been imputed sufficient, or must the hearer understand that a specific offense has been charged? Fourth, must the hearer correctly understand the applicable criminal law?

The first inquiry is that to which the rule of $\$ 563$ of the Restatement of Torts is addressed and properly can be answered only in the affirmative. Surely, it is obvious that, unless the hearer actually grasps the factual content of the communication, there has been no communication and, consequently, no defamation has occurred.

The second inquiry-whether the hearer must realize that the facts communicated amount to an imputation of criminality-is more difficult. Just as the defamer does not usually slander in terms of the criminal code, so the average hearer's mind does not analyze in terms of the criminal law. Two generally disparate approaches have been taken to this problem: the one inquiring into the actual understanding of the hearers, and the other disregarding this point, either silently or by presuming a complete knowledge of the criminal law in the hearer, which amounts to the same thing.

As regards the first approach, there is some authority for the proposition that, where hearers reasonably understand a defamatory utterance to impute a crime, it is actionable per se, despite the fact that the 
conduct described is, in law, entirely innocent. ${ }^{68}$ It is difficult to quarrel with the extension of liability on this basis. The logical converse of this proposition would be that, where the conduct imputed by the defamatory utterance is in fact criminal, but the hearers are unaware of this, the defamatory statement is not actionable per se. The law has not, however, adopted this corollary rule, as the cases taking the second approach demonstrate.

With respect to the second approach, although the statement has been repeated innumerable times that the hearers must understand the words used as an imputation of crime, ${ }^{69}$ close analysis casts great doubt on its validity. Individual hearers are not ordinarily permitted to testify as to the meaning they placed on the defamatory utterance, ${ }^{70}$ although all surrounding facts and circumstances are admissible to show its meaning. ${ }^{71}$ This would seem to indicate that the actual understanding of the hearer is not significant. This theory seems to be supported by the cases which hold that an imputation of crime made concerning acts "known to be innocent" by the hearers is not actionable per se, thus effectively attributing to the hearers a fictitious knowledge of the criminal law. ${ }^{72}$ There are, moreover, other cases which do not expressly impute any knowledge of the criminal law to the hearers, but rather get over the problem by ignoring it. In Brooks v. Harison, ${ }^{73}$ for example, the defendant stated that the plaintiff, owner of a dairy, kept his cows in with a diseased horse and that their milk was impure. A jury was permitted to find an imputation of the statutory misdemeanor of trafficking in impure milk. And in Selig v. Alexander, ${ }^{74}$ the defendant stated that he had not authorized the plaintiff to sell his brandy as Hennesy's and that plaintiff had no authority to do so. This was held to be sufficient imputation of the statutory crime of an offense against a trade-mark. Perhaps Frazier v. Grob, ${ }^{75}$ in its colorful way, best illustrates the case where the defamatory statement is understood in its factual content, but evokes in the hearer moral disapproval rather than a realization that a criminal statute has been violated. In all these cases the jury was permitted to find that the defamatory state-

${ }^{88}$ Note, 29 HARv. L. Rev. 857 (19:6).

${ }^{10}$ Kegerreis v. Van Zile, I80 App. Div. 414, 167 N.Y. Supp. 874 (1917); Wolrath v. Nellis, 17 How. Pr. 72 (N.Y. 1859 ).

${ }^{70}$ WIGMORE, EVIDENCE $\$ 1971$ (3rd ed. 1940). See also Odgers, op. cit. sitpra note 66 at 105 .

${ }^{71}$ SeELman, op. cit. supra note 52 at pp. 634-638.

${ }^{72}$ Pike v. Von Wormer, 5 How. Pr. 171 (N.Y. 1850); Divers v. Meredith, 147 Ind. 693,47 N.E. 143 (1897).

${ }^{73} 9$ I N.Y. 83 (1883).

${ }^{74} 173$ N.Y. Supp. 187 (1918).

${ }^{75}{ }_{194}$ Mo. App. 405, 183 S.W. 1083 (1916). 
ments imputed crimes, although it seems doubtful that they were reasonably understood by the actual hearers to have been charges of crime.

As a result, there is doubt as to whether or not the hearers of a defamatory statement must realize that a crime has been imputed, the probability being that they need not. If, indeed, this is so, then an accusation of Communism may permissibly be found to impute a crime, despite the prevailing popular ignorance of the applicable law. Although dicta abound there seems to be no direct authority on this question. The cases discussed above are only noted because it seems impossible to explain them on any basis other than a negative determination of this question, although they do not expressly discuss it.

On the other hand, however, there is no better authority for the proposition that the hearers must realize that criminality has been imputed. But, assuming that they must, this poses our third and fourth inquiries; namely, whether the hearer must recognize the defamatory utterance as imputing general criminality or a specific offense, and whether the hearer must correctly understand the applicable criminal law.

Concerning the third inquiry, the word "Communist" probably is not actionable per se as an imputation of general criminality. This follows from the fact that such epithets as "crook" and "gangster," which also carry this connotation, have not generally been held to be actionable per $s e^{76}$ The majority view would apparently require an imputation of some specific offenses-although there is some authority to the contrary. ${ }^{77}$ Thus, in Devany v. Quill, where the defendant, during World War II, termed the plaintiff "The agent of Fascism in America today" and "The agent of Hitler in America," the court stated:

And while it is not a charge of specific crime, it is a charge of any and all such crimes which "the agent" of Hitler or Fascism in this country had committed or which he might be expected to commit as such agent. At least the jury might have so found. ${ }^{78}$

This case probably can be supported as an extension of the holdings that an oral charge of felony is actionable per se, though the crime is not specifically named. ${ }^{79}$ It would agree as well with the older English cases holding that an accusation of a "deed without a name" may be

${ }^{70}$ Villemin v. Brown, 193 App. Div. 777 (1920); Hofstadter v. Bienstock, 213 App. Div. 807. (1925); Prosser, Torts $\$ 92$, p. 805 (ist ed. 194I); SeElman, op. cit. supra note 52 at pp. 630-633.

${ }_{77}$ Weiner v. Leviton, 230 App. Div. 312 (1930).

${ }^{78} 64$ N.Y.S.2d 733,736 (1946).

${ }^{70}$ Newell, SLANDER AND Libel 9I (4th ed. 1924). 
actionable per se..$^{80}$ But the force of this argument is mitigated by the fact that an accusation of neither Fascism nor Communism as graphically imports violation of the criminal law as does an accusation of felony or the language used in the "deed without a name" cases. Such cases, moreover, have been severely criticized, ${ }^{81}$ and an action based on their underlying theory would seem to be on very treacherous ground. It would be preferable to allow the accusation of Communism to stand on its own feet, if it will, as an accusation of one of the specific offenses discussed above.

With respect to the fourth inquiry, if the hearer must correctly understand the applicable criminal law, an accusation of Communismor of any crime, for that matter-would almost never be slander per se, as an imputation of crime. ${ }^{82}$ Fortunately, it seems unlikely that any court would knowingly impose such a requirement. A more reasoned approach would seem to be that any realization by the hearer that some specific crime has been ascribed to the plaintiff is sufficient to make the statement actionable per se. It would seem accurate to say that, if the hearer believes, as does a substantial group of people today, that "cit is a crime to be a Communist," this would suffice to make an accusation of Communism actionable per se.

To recapitulate, the first step in the interpretation of a statement alleged to be slanderous per se as an imputation of crime is a determination by the court as to whether or not the defamatory statement, coupled with a suitable innuendo, will reasonably bear the meaning that the plaintiff has violated a sufficiently serious criminal statute. It seems probable that an accusation of Communism, with an innuendo, would reasonably bear the meaning that the plaintiff has violated the Smith Act. In Massachusetts, it would almost certainly reasonably bear the meaning that the plaintiff has violated the statute relating to membership in subversive organizations. The problem here is whether the term "Communist" has picked up factual connotations embracing the principal elements of these offenses clearly and definitely enough. It would seem that it has done so, when measured by the standard of the past cases. Since the accusation can reasonably bear the necessary factual content, the case, then, is one for the jury.

Exactly what standard a jury must apply in order to determine whether a defamatory utterance constituted an imputation of crime is

${ }^{80}$ See cases collected in NEWELI, op. cit. supra note 79 at pp. 92-93; and in ODGERS, op. cit. supra note 66 at 36 .

${ }^{31}$ SEELMAN, op. cit. supra note 52 at pp. 632-633.

${ }^{82}$ The average hearer simply does not understand the criminal law applicable to the commonest and most obviously actionable accusations. For example, although he realizes that the statement that "Doe killed Roe" imputes a crime, he would be unable to give a satisfactory statement of the elements of this familiar offense. 
somewhat doubtful. Certainly, it must find that the factual content of the statement was understood by the hearers. There is some question as to whether the jury must find also that the hearers understood the conduct imputed to be criminal. But, if the jury must so find, they" probably must find that the hearers understood the term "Communist" as charging a specific offense, and not merely that Communists are persons who generally commit crimes. The jury certainly need not find that the hearers correctly understood the applicable criminal law.

To date, four cases have directly considered the question of whether an accusation of Communism may be found to impute a criminal offense. None of these cases is remarkable for its analysis of the problems involved. The dicta in Remington $v$. Bentley, ${ }^{83}$ reaching a negative result, does so by adopting an error made in certain libel cases, creating a false distinction between "libel per se" and "libel per quod."84 The direct negative holding in Keefe $v$. O'Brien ${ }^{85}$ seems more concerned with expressing moral disapproval of Communists and Communism than with formulating a legal rationale as to why the case should not be permitted to go to the jury. The same result was reached in Ohio in Pecyk v. Semoncheck. ${ }^{86}$ The most recent case, however, Lightfoot $v$. Jennings, ${ }^{87}$ held the accusation of Communism actionable per se as imputing a violation of the Smith Act. This result would seem clearly correct.

It is unfortunate that legal rights should depend on tiresome and illogical distinctions of the sort that pervade the entire law of slander. Since it is generally agreed that the requirement of "temporal damages" is basically erroneous, ${ }^{88}$ it would seem proper in any genuinely doubtful case to hold that a defamatory accusation amounts to slander per se, thus avoiding a decision which may turn on the accident of provable temporal damages. What is really needed is a thorough reform of the law of slander; but it is not encouraging to notice the dearth of results that has followed advocacy of reform by some of the finest scholars in the field. ${ }^{89}$

${ }^{83} 88$ F. Supp. 166, 170 (S.D.N.Y. 1949).

Frank E. Booker

${ }^{84}$ Seelman, op. cit. supra note 52 at 34 ; Prosser, op. cit. supra note 76 at pp. 797-798.

${ }^{85}$ II6 N.Y.S.2d 286 (1952).

${ }^{80} 105$ N.E.2d 6I (Ohio 1952).

${ }_{25} 54$ S.W.2d 596 (Mo. 1953 ).

${ }^{88}$ I Street, Foundations of Legal Liability 280 (ist ed. 1906). Pollock, TORTs 243 (i2th ed. 1923); HOLDSWORTH, op. cit. supra note 5, at 304.

${ }^{80}$ Holdsworth, Defamation in the Sixteenth and Seventeenth Centuries, 4 I L.Q. Rev. I3, 3I (1925); Prosser, TORTS $\$ 92$, pp. 807-809 (Ist ed. I941); STREET, op. cit. supra note 88. 